\title{
RESEARCH PAPER \\ Aggressive Citrus tristeza virus isolates in Chile are MCA13-positive and VT type, while mild isolates are MCA13-negative and T30 type
}

\author{
Ximena Besoain ${ }^{1}$, Edson Bertolini² ${ }^{2}$ Rocío Camps ${ }^{1}$, Fiona Ramella ${ }^{1}$, María Teresa \\ Gorris $^{2}$, Margarita Torres ${ }^{1}$, and Mariano Cambra ${ }^{2}$ \\ ${ }^{1}$ Facultad de Ciencias Agronómicas y de los Alimentos, Pontificia Universidad Católica de Valparaíso, \\ Casilla 4-D, Quillota, Chile. \\ ${ }^{2}$ Instituto Valenciano de Investigaciones Agrarias, Apdo. Oficial, 46113, Moncada, Valencia, Spain.
}

\begin{abstract}
X. Besoain, E. Bertolini, R. Camps, F. Ramella, M.T. Gorris, M. Torres, and M. Cambra. 2015. Aggressive Citrus tristeza virus isolates in Chile are MCA13-positive and VT type, while mild isolates are MCA13-negative and T30 type. Cien. Inv. Agr. 42(2):251-262. Citrus tristeza virus (CTV) was reported in the 1960's to affect Meyer lemon trees in Chile, but no field symptoms were observed. This study performed a complete biological, serological and molecular characterization of one hundred CTV isolates obtained from different hosts and geographical origins. Decline symptoms (DI) were not found on trees grafted onto sour orange. In Pica Oasis in northern Chile, stem pitting (SP) was found to affect grapefruit and Mexican lime trees. Most isolates present in the central area were considered mild (MCA-13-negative), while in the northern area aggressive isolates were observed and detected. Some of these isolates were capable of causing SP on grapefruit under field and greenhouse conditions and on sweet orange under greenhouse conditions. Almost all of these isolates were MCA13-positive and had nucleotide sequences associated with the VT genotype.
\end{abstract}

Key words: Biological indexing, CTV, molecular characterization, stem pitting, seedling yellows.

\section{Introduction}

Citrus tristeza virus (CTV) is most likely present in all citrus-producing countries worldwide (CABI, 2010), although its prevalence is highly variable. It has been detected in isolated trees and is not yet considered an epidemic in many countries in the Mediterranean, Near East, and Central and South America (Cambra and Moreno, 2000;

Received January 27, 2015. Accepted June 26, 2015. Corresponding author: xbesoain@ucv.cl
Moreno et al., 2008), including Chile (Weathers and Sánchez, 1970).

There are three major syndromes associated with this pathogen: i) tristeza caused by CTV isolates that are decline-inducing (DI) on citrus trees that have been grafted onto sour orange (Citrus aurantium L.) or lemon (C. limon (L.) Burm.f.) trees; ii) stem pitting (SP), which is produced in grapefruits (C. paradisi Macf.) or sweet oranges (C. sinensis (L.) Osbeck); and iii) seedling yellows (SY), which affects sour oranges, lemons and 
grapefruits and normally occurs under greenhouse conditions (Moreno et al., 2008).

Garnsey et al. (1987) proposed a standardized evaluation for the biological characterization of CTV isolates by assessing biological characteristics (SHR) of the CTV isolates on five different hosts that are especially sensitive to the virus. This approach would allow the characterization of the biological properties of the CTV isolates analyzed to date.

For the serological characterization, Vela et al. (1986) were the first to produce monoclonal antibodies (MAbs) specifically for the detection of CTV and demonstrated that the combination of 3DF1 and 3CA5 was capable of detecting all of the CTV isolates found at that time (Cambra et al., 1990). The CTV coat protein contains multiple epitopes; this characteristic allowed Permar et al. (1990) to develop a monoclonal antibody (MCA13) capable of reacting to isolates that were considered aggressive in Florida (USA), isolates capable of inducing DI in sweet orange grafted onto sour orange trees, SY in sour oranges, and SP in grapefruits. In contrast, MCA-negative isolates were only capable of inducing symptoms on Mexican limes or $C$. macrophylla. Permar and Garnsey (1991) found a 90 to $95 \%$ correlation between the aggressiveness of the CTV isolates and their reaction with MCA13. However, in Spain the reaction with MCA13 was not totally correlated with the presence of DI symptoms (Cambra et al., 1993).

For the molecular characterization of CTV, Hilf and Garnsey (2000) and Hilf et al. (2005) proposed a classification based on the use of 11 pairs of oligonucleotide primers for RT-PCR. This study involved the use of a universal primer $\mathrm{T}-36$ (T36CP) that targeted the coat protein of the isolate, plus 10 primer sets. Three of the primer sets targeted the polymerase region, three the K17 region, three the extreme 5' of the T-36, T-30 and VT isolates, and one the K17 zone of the T-3 isolate. The isolates were classified into 14 groups in this study, although the majority consisted of variants of the T3, T30, T36 and VT isolates. Recent phylogenetic studies have determined that these isolates show clear divergence (Moreno et al., 2008; Biswas, 2010; Brlansky et al., 2011; Harper 2013; Wang et al., 2013).

In Chile, the importance of the citrus industry has been increasing and has oriented towards the export of fresh fruit, especially lemons, sweet oranges, and mandarins (ODEPA, 2013). In the late 1960's, the presence of CTV was reported in nearly 2000 Meyer lemon trees throughout Chile (Weathers and Sánchez, 1970). In a more recent study by Besoain et al. (2008), CTV was detected in sweet orange, tangelo, Mexican lime, and grapefruit trees in orchards from the Tarapacá Region to the O'Higgins Region through the use of biological indexing and serology. The CTV prevalence was $0.38 \%$ (Besoain, 2008). However, neither the DI nor SP symptoms were observed throughout all of the citrus orchards studied by the researchers.

The objective of this study was to completely characterize 100 Chilean CTV isolates collected during a previous survey using biological and serological approaches and multiple molecular markers (MMM).

\section{Materials and methods}

\section{CTV isolates}

A collection of Chilean CTV isolates was established through citrus orchard sampling. The isolates were maintained in Mexican lime and/or sweet orange plants in the Citrus Germplasm Virus and Viroids Collection at the Estación Experimental La Palma of the Escuela de Agronomía, Pontificia Universidad Católica de Valparaíso. From this collection, 100 representative CTV isolates were selected from different geographic locations and citrus host species (Besoain, 2008). 
Biological characterization of the Chilean CTV isolates

The biological characterization of the Chilean CTV isolates was accomplished using the SHR protocol (Garnsey et al., 1987; Wang et al., 2013). Four plants of five indicator species were used per isolate: Mexican lime, sour orange, Duncan grapefruit, Madame Vinous sweet orange, and Madame Vinous sweet orange grafted onto sour orange. In this last group, plants found to be CTV-positive after the testing were grafted onto the sweet orange scion with a healthy bud of sour orange to determine which isolates were capable of inducing DI (Pina et al., 2004). Then, the trees were maintained for one year under greenhouse conditions with temperatures between $18-26{ }^{\circ} \mathrm{C}$ (Roistacher, 1991). The presence or absence of symptoms was evaluated every six months. The grapefruits were grown under temperatures that oscillated between 32 and $38^{\circ} \mathrm{C}$ after the second year, as suggested by Broadbent et al. (1996), to stimulate the symptoms of severe stem pitting and the development of deep depressions in the wood.

\section{Serological characterization}

The serological characterization of the 100 Chilean CTV isolates was performed using DASI-ELISA (Cambra et al., 1991) with 12 MAbs: 3DF1, 3CA5 and 3BH6 from Spain (Vela et al., 1986), MCA13 from Florida, USA (Permar et al., 1990), C1F10 from Cuba (Besoain, 2008), ECTV176 and ECTV178 from Florida, USA (Garnsey, not published), 3E10 and 4H6H from Taiwan (Tsai et al., 1993), and $\alpha$ CTV4E5-a1, $\alpha$ CTV4B1-3 and $\alpha$ CTVF3-a1 from Morocco (Besoain, 2008).

The following isolates were used as the positive CTV controls: the mild Mediterranean T-300 isolate (Ballester-Olmos et al., 1993); the aggressive T-388 isolate; and the T-397-P isolate, which has a defective epitope recognized by the antibody 3DF1 (Cambra et al., 1993). Healthy plants were used as negative controls. The extracts were prepared by homogenizing samples of vegetative material (1:10 p/v; sample/extraction buffer) in 0.14 M PBS (pH 7.2 to 7.4) supplemented with $0.2 \%$ sodium dimethyl dithiocarbamate (DIECA) (Cambra et al., 1991). The DASI-ELISA was performed according to the method of Cambra et al. (1993). The ELISA plates (Nunc Polisorp) were coated with $1 \mu \mathrm{g} \mathrm{mL} \mathrm{m}^{-1}$ of polyclonal immunoglobulins. The MAbs diluted in PBS ( $\mathrm{pH}$ 7.2-7.4) included: 3DF1 $\left(0.05 \mu \mathrm{g} \mathrm{mL}^{-1}\right)$; 3CA5 (0.5 $\left.\mu \mathrm{g} \mathrm{mL} \mathrm{mL}^{-1}\right)$; MCA13 (1/10,000 ascites fluid); 3BH6 $\left(0.25 \mu \mathrm{g} \mathrm{mL}^{-1}\right)$; C1F10 (0.25 $\left.\mu \mathrm{g} \mathrm{mL}^{-1}\right)$; 4H6H $(0.5$ $\left.\mu \mathrm{g} \mathrm{mL}{ }^{-1}\right) ; \mathrm{ECTV}-176\left(1.0 \mu \mathrm{g} \mathrm{mL}^{-1}\right) ; \mathrm{ECTV}-178$ (1/1,000 ascites fluid); $4 \mathrm{~F} 3 \alpha 1\left(0.2 \mu \mathrm{g} \mathrm{mL}^{-1}\right) ; 3 \mathrm{E} 10$ (1/5,000 ascites fluid); $\alpha$ CTV4E5-a1 $\left(0.1 \mu \mathrm{g} \mathrm{mL}^{-1}\right)$ and $\alpha \mathrm{CTV} 4 \mathrm{~B} 1-34 \mathrm{~F} 3\left(0.1 \mu \mathrm{g} \mathrm{mL}^{-1}\right)$. The optical density $\left(\mathrm{DO}_{405}\right)$ was measured after 60 minutes using a Titerek Multiskan (Flow). The samples were considered positive if the $\mathrm{DO}_{405}$ exhibited a two-fold increase over the negative control.

\section{Molecular characterization}

The $100 \mathrm{CTV}$ isolates were characterized using the methodology described by Hilf et al. (2005). A total of $0.5 \mathrm{~g}$ of shoot tissue was collected for each sample analyzed. The CTV extraction was performed by combining the lyophilized sample with $4 \mathrm{ml}$ of extraction buffer (PBS ( $\mathrm{pH}$ 7.2 to 7.4 ) supplemented with sodium diethyl dithiocarbamate (DIECA)) and homogenizing in individual polyethylene bags (Bioreba) using the Homex 6000 (Bioreba). Viral RNA extraction was performed using the RNeasy ${ }^{\circledR}$ Plant Mini Kit (Qiagen).

One-step RT-PCR was performed using the primers Pin1/Pin2 (Olmos et al., 1999) and the 11 primers pairs described by Hilf et al. (2005). The reaction cocktail was composed of $25 \mu \mathrm{L}$ mix for RT-PCR (10 mM Tris- $\mathrm{HCl}$ (pH 8.8), $50 \mathrm{mM} \mathrm{KCl}, 1.5 \mathrm{mM}$ $\mathrm{MgCl}_{2}$, and $0.3 \%$ Triton X100 (w/v)), $1 \mu \mathrm{M}$ of each primer, $250 \mu \mathrm{M}$ dNTPs, 0.25 units of AMV-RT (Promega), 0.5 units of Taq Polymerase (Promega) and $5 \mu \mathrm{L}$ of RNA template. The conditions for 
RT-PCR were: one cycle of retrotranscription at $42{ }^{\circ} \mathrm{C}$ for $45 \mathrm{~min}$, followed by 40 amplification cycles at $94^{\circ} \mathrm{C}$ for 30 seconds, $56^{\circ} \mathrm{C}$ for $1 \mathrm{~min}$ and $72{ }^{\circ} \mathrm{C}$ for $1 \mathrm{~min}$, and a final cycle at $72{ }^{\circ} \mathrm{C}$ for 10 min. Electrophoresis was performed using a $2 \%$ agarose gel stained with ethidium bromide, and the bands were observed using ultraviolet light.

\section{Results}

\section{Biological characterization of isolates}

Biological groups obtained through the biological characterization of the 100 Chilean CTV isolates are shown in Table 1. Eleven groups were estab- lished (including the 5' and 8' groups), and another four groups were not completely biologically characterized $\left(\mathrm{ND}_{1}\right.$ to $\left.\mathrm{ND}_{4}\right)$. Based on the results of the biological characterization, the majority of the CTV isolates collected in Chile (56\%) showed characteristics of mild or moderate isolates (i.e., only caused a reaction in Mexican limes and/or DI in the combination sweet orange/sour orange plants; Symptoms profiles 7, 13, and $\mathrm{ND}_{4}$ ).

For the rest of the CTV isolates, only $17 \%$ were capable of causing SP. This included $11 \%$ in grapefruits, $8 \%$ of which were found in Pica and Matilla, Tarapacá Region (Figure 1A and B) and $3 \%$ in Ovalle, Coquimbo Region. Six isolates were demonstrated to be capable of causing SP

Table 1. Symptom profiles obtained from the biological characterization of one hundred Chilean Citrus tristeza virus isolates.

\begin{tabular}{|c|c|c|c|c|c|c|}
\hline $\begin{array}{l}\text { Symptom } \\
\text { Profiles }\end{array}$ & Mexican lime & $\begin{array}{c}\text { DI }^{1} \\
\text { Sweet orange/ } \\
\text { sour orange }\end{array}$ & $\begin{array}{c}\text { SY on } \\
\text { Sour orange }\end{array}$ & $\begin{array}{c}\text { SP on } \\
\text { Sweet orange }\end{array}$ & $\begin{array}{c}\text { SP on } \\
\text { Grapefruit cv. } \\
\text { Duncan }\end{array}$ & $\begin{array}{c}\mathrm{N}^{0} \text { of Chilean CTV } \\
\text { isolates/Group }\end{array}$ \\
\hline 1 & + & + & + & + & + & 0 \\
\hline 2 & + & + & + & + & - & 2 \\
\hline 3 & + & + & + & - & + & 2 \\
\hline 4 & + & + & + & - & - & 18 \\
\hline 5 & + & + & - & - & + & 4 \\
\hline 5, & + & + & - & + & - & 2 \\
\hline 6 & + & + & - & + & + & 0 \\
\hline 7 & + & + & - & - & - & 33 \\
\hline 8 & + & - & + & + & + & 0 \\
\hline $8^{\prime}$ & + & - & + & + & - & 1 \\
\hline 9 & + & - & + & - & + & 1 \\
\hline 10 & + & - & + & - & - & 5 \\
\hline 11 & + & - & - & + & + & 0 \\
\hline 12 & + & - & - & - & + & 3 \\
\hline 13 & + & - & - & - & - & 20 \\
\hline 14 & - & - & - & - & - & 0 \\
\hline $\mathrm{ND}_{1}$ & + & $\mathrm{ND}$ & + & - & - & 4 \\
\hline $\mathrm{ND}_{2}$ & + & ND & - & + & - & 1 \\
\hline $\mathrm{ND}_{3}$ & + & ND & - & - & + & 1 \\
\hline $\mathrm{ND}_{4}$ & + & ND & - & - & - & 3 \\
\hline Total & 100 & 61 & 33 & 6 & 11 & 100 \\
\hline
\end{tabular}

${ }^{1}$ DI biological test proposed by Pina et al. (2004).

${ }^{2}$ Symptom profiles for CTV isolates proposed by Hilf et al. (2005), modified by adding the 05 ' profile. $\mathrm{DI}=$ Decline inducing, $\mathrm{SY}=$ Seedling yellows, $\mathrm{SP}=$ Stem pitting, $\mathrm{ND}=$ Not determined (the $\mathrm{DI}$ test proposed by Pina et al. (2004) was not performed). 


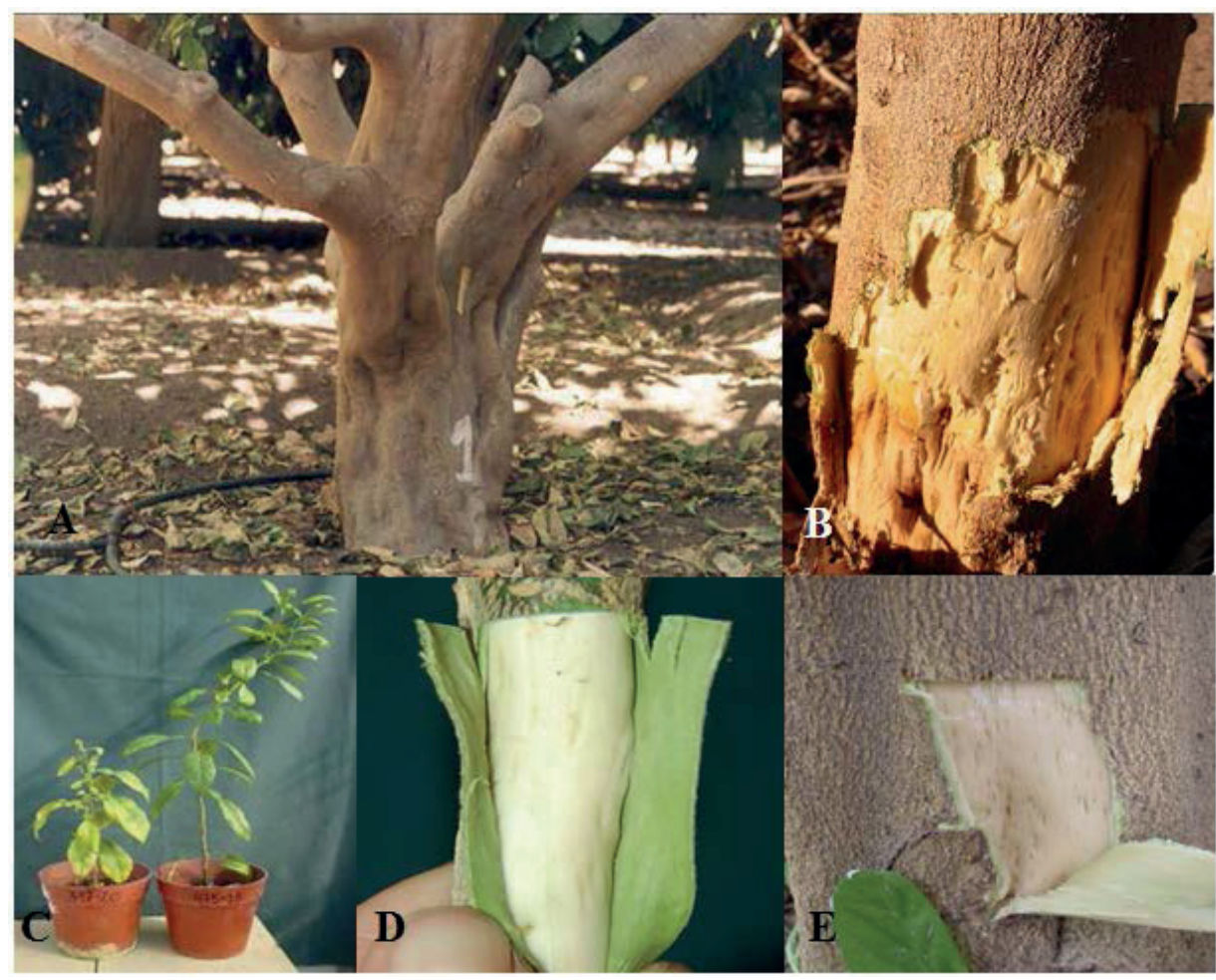

Figure 1. A. Symptoms of severe stem pitting on Marsh grapefruit trees, where deformation of the trunk and branches can be observed. B. Star Ruby grapefruit tree with severe stem pitting depressions in the wood and overgrown, thick bark. C. Left, symptoms of seedling yellows developing on a sour orange seedling tree. D. Duncan grapefruit indicator plant inoculated with a CTV isolate capable of inducing stem pitting in the wood. E. Stem pitting observed on C. macrophylla rootstock grafted with lemon in Ovalle.

in sweet oranges; all of these isolates were from the Tarapacá Region (Pica Oasis and Camiña). Symptoms of SY in sour oranges were produced by $33 \%$ of the Chilean isolates studied (Table 1, Figure 1C). Additionally, some isolates were capable of causing vein corking in sour oranges and/or Mexican limes.

Generally, there was agreement between the reaction or severity of symptoms observed in the indicator plants and the symptoms observed in the field. Thus, the isolates 42-4, 92-2, 507, 509 and 510 (Table 2) obtained from grapefruit trees with SP symptoms yielded symptoms of this type on the Duncan grapefruit indicator plants (Figure 1D). However, the isolates 494, 495, and 497 obtained from an orchard of Eureka lemons grafted onto C. macrophylla in Ovalle caused SP in grapefruits. The trees were asymptomatic at the time these isolates were collected, but four years later it was possible to observe the development of symptoms on the wood of the rootstocks (Figure 1E). Finally, SP was observed in sweet orange trees grown in a greenhouse, denoting the presence of aggressive CTV isolates capable of causing damage independent of the rootstock used. However, this syndrome was not observed on later samples of CTV-infected sweet orange trees grown in the field.

\section{Serological characterization of CTV isolates}

Eight serogroups were established from the $100 \mathrm{CTV}$ isolates through the use of 12 different MAbs (Table 2). The majority (57\%) of the isolates from this study reacted to the entire panel of MAbs; these were classified as sero- 
Table 2. Biological, serological and molecular classification of Citrus tristeza virus isolates obtained from orchards in eight Chilean citrus producing regions.

\begin{tabular}{|c|c|c|c|c|c|c|c|}
\hline Region & Locality & Host & Isolate & $\begin{array}{l}\text { Biological } \\
\text { Group }\end{array}$ & $\begin{array}{l}\text { Serological } \\
\text { Group }\end{array}$ & $\begin{array}{c}\mathrm{MCA} \\
13\end{array}$ & $\begin{array}{c}\text { Molecular }^{1} \\
\text { Characterization }\end{array}$ \\
\hline Atacama & Vallenar & Sweet orange & $281-1$ & 7 & 5 & Neg & $\begin{array}{l}\text { VT- } \\
\text { VTPol+T30Pol }\end{array}$ \\
\hline Tarapacá & Comiña & Sweet orange & $101-3$ & 7 & 1 & Pos & VT-VTPol \\
\hline Tarapacá & Matilla & Grapefruit & $179-1$ & 7 & 1 & Pos & VT-VTPol \\
\hline Tarapacá & Matilla & Mexican lime & $96-5$ & 7 & 1 & Pos & VT-VTPol \\
\hline Tarapacá & Pica & Grapefruit & $42-4$ & 12 & 1 & Pos & VT-VTPol \\
\hline Tarapacá & Pica & Grapefruit & $92-2$ & 12 & 1 & Pos & VT-VTPol \\
\hline Tarapacá & Pica & Grapefruit & 511 & 4 & 1 & Pos & VT-VTPol \\
\hline Tarapacá & Pica & Mexican lime & $95-5$ & 7 & 1 & Pos & VT-VTPol \\
\hline Tarapacá & Pica & Mexican lime & $95-6$ & 13 & 1 & Pos & VT-VTPol \\
\hline Tarapacá & Pica & Mexican lime & $106-5$ & 7 & 1 & Pos & VT-VTPol \\
\hline Tarapacá & Pica & Sweet orange & $89-2$ & 7 & 1 & Pos & VT-VTPol \\
\hline Tarapacá & Pica & Sweet orange & $88-2$ & 3 & 1 & Neg & VT-VTPol \\
\hline Tarapacá & Pica & Grapefruit & $42-3$ & 12 & 4 & Pos & VT-VTPol \\
\hline Tarapacá & Matilla & Sweet orange & $240-1$ & 7 & 1 & Pos & VT-VT5' \\
\hline Tarapacá & Pica & Mexican lime & 327 & 7 & 1 & Pos & VT-VT5 \\
\hline Tarapacá & Pica & Mexican lime & 521 & 4 & 1 & Pos & VT-VT5, \\
\hline Tarapacá & Pica & Mexican lime & 524 & 2 & 1 & Pos & VT-VT5, \\
\hline Tarapacá & Pica & Sweet orange & 337 & 7 & 3 & Pos & VT-VT5 \\
\hline Tarapacá & Pica & Grapefruit & 510 & 12 & 1 & Pos & VTK17 \\
\hline Tarapacá & Pica & Grapefruit & 514 & 4 & 1 & Pos & VT5 \\
\hline Arica y Parinacota & Azapa & Sweet orange & $232-2$ & 4 & 1 & Pos & $\mathrm{VT}+\mathrm{T} 30 \mathrm{~K} 17$ \\
\hline Arica y Parinacota & Azapa & Sweet orange & $231-1$ & $\mathrm{ND}_{1}$ & 1 & Pos & $\mathrm{VT}+\mathrm{T} 30 \mathrm{~K} 17$ \\
\hline Tarapacá & Matilla & Mexican lime & $301-21$ & 4 & 1 & Pos & $\mathrm{VT}+\mathrm{T} 30 \mathrm{~K} 17$ \\
\hline Tarapacá & Pica & Mexican lime & $84-1$ & 4 & 1 & Pos & $\mathrm{VT}+\mathrm{T} 30 \mathrm{~K} 17$ \\
\hline Tarapacá & Pica & Mexican lime & $83-3$ & 4 & 1 & Pos & $\mathrm{VT}+\mathrm{T} 30 \mathrm{~K} 17$ \\
\hline Tarapacá & Pica & Sweet orange & $87-5$ & 4 & 1 & Pos & $\mathrm{VT}+\mathrm{T} 30 \mathrm{~K} 17$ \\
\hline Tarapacá & Comiña & Sweet orange & $101-2$ & 7 & 1 & Pos & $\mathrm{VT}$ \\
\hline Tarapacá & Comiña & Sweet orange & $101-4$ & 7 & 1 & Pos & VT \\
\hline Tarapacá & Comiña & Sweet orange & $101-5$ & 4 & 1 & Pos & VT \\
\hline Tarapacá & Comiña & Sweet orange & $101-6$ & 7 & 1 & Pos & VT \\
\hline Tarapacá & Comiña & Sweet orange & $301-34$ & 5 & 1 & Pos & VT \\
\hline Tarapacá & Comiña & Sweet orange & $301-34 \mathrm{~B}$ & $\mathrm{ND}_{2}$ & 1 & Pos & VT \\
\hline Tarapacá & Matilla & Mexican lime & $96-3$ & 4 & 1 & Pos & VT \\
\hline Tarapacá & Matilla & Mexican lime & $96-1$ & 7 & 1 & Pos & VT \\
\hline Tarapacá & Matilla & Mexican lime & $301-7$ & 7 & 1 & Pos & VT \\
\hline Tarapacá & Matilla & Mexican lime & $301-25 B$ & 13 & 1 & Pos & VT \\
\hline Tarapacá & Matilla & Mexican lime & 301-30B & 13 & 1 & Pos & VT \\
\hline Tarapacá & Matilla & Mexican lime & $96-6$ & 5 & 1 & Pos & VT \\
\hline Tarapacá & Matilla & Sweet orange & $244-1$ & 4 & 1 & Pos & VT \\
\hline Tarapacá & Matilla & Tangelo & $246-2$ & 7 & 1 & Pos & VT \\
\hline Tarapacá & Pica & Grapefruit & 508 & 5, & 1 & Pos & VT \\
\hline Tarapacá & Pica & Mexican lime & $301-2$ & 4 & 1 & Pos & VT \\
\hline Tarapacá & Pica & Mexican lime & $301-6$ & 4 & 1 & Pos & VT \\
\hline Tarapacá & Pica & Mexican lime & $95-3$ & 7 & 1 & Pos & VT \\
\hline Tarapacá & Pica & Mexican lime & $106-3$ & 7 & 1 & Pos & VT \\
\hline Tarapacá & Pica & Mexican lime & $106-4$ & 4 & 1 & Pos & VT \\
\hline Tarapacá & Pica & Mexican lime & $85-1$ & 4 & 1 & Pos & VT \\
\hline Tarapacá & Pica & Mexican lime & $301-5$ & 8, & 1 & Pos & VT \\
\hline Tarapacá & Pica & Mexican lime & $301-9$ & 13 & 1 & Pos & VT \\
\hline Tarapacá & Pica & Mexican lime & $301-11$ & 13 & 1 & Pos & VT \\
\hline Tarapacá & Pica & Sweet orange & $301-41 B$ & 7 & 1 & Pos & VT \\
\hline
\end{tabular}


Continuation Table 2

\begin{tabular}{|c|c|c|c|c|c|c|c|}
\hline Tarapacá & Pica & Sweet orange & $301-44 B$ & 7 & 1 & Pos & VT \\
\hline Tarapacá & Pica & Sweet orange & 334 & 3 & 1 & Pos & VT \\
\hline Tarapacá & Pica & Mexican lime & $301-10$ & 10 & 8 & Neg & $\mathrm{VT}$ \\
\hline O'Higgins & Lolol & Sweet orange & 490 & 7 & 2 & Neg & T30Pol \\
\hline O'Higgins & Perailillo & Limonero & 491 & 13 & 7 & Neg & T30Pol \\
\hline O'Higgins & Nancagua & Sweet orange & 462 & 7 & 2 & Neg & $\mathrm{T} 30 \mathrm{~K} 17+\mathrm{T} 30 \mathrm{Pol}$ \\
\hline O'Higgins & Nancagua & Sweet orange & 464 & 7 & 2 & $\mathrm{Neg}$ & $\mathrm{T} 30 \mathrm{~K} 17+\mathrm{T} 30 \mathrm{Pol}$ \\
\hline Valparaíso & Limache & Sweet orange & $305-1$ & 7 & 1 & Pos & T30K17 \\
\hline Valparaíso & Limache & Sweet orange & $305-1 \mathrm{~B}$ & 13 & 2 & Neg & T30K 17 \\
\hline Valparaíso & Limache & Sweet orange & $305-8 \mathrm{~B}$ & 13 & 2 & Neg & T30K17 \\
\hline Valparaíso & Limache & Sweet orange & $305-15 B$ & 7 & 2 & $\mathrm{Neg}$ & T30K17 \\
\hline Valparaíso & Limache & Sweet orange & $305-3$ & 3 & 2 & Neg & T30K17 \\
\hline Valparaíso & Limache & Sweet orange & $305-7$ & 7 & 2 & $\mathrm{Neg}$ & T30K17 \\
\hline Valparaíso & Limache & Sweet orange & $305-8$ & $\mathrm{ND}_{1}$ & 2 & $\mathrm{Neg}$ & Т30K17 \\
\hline Valparaíso & Limache & Sweet orange & $305-14$ & 7 & 2 & $\mathrm{Neg}$ & T30K 17 \\
\hline Valparaíso & Limache & Sweet orange & $305-16$ & $\mathrm{ND}_{4}$ & 2 & $\mathrm{Neg}$ & T30K17 \\
\hline Valparaíso & Limache & Sweet orange & $305-5 B$ & 4 & 2 & $\mathrm{Neg}$ & T30K17 \\
\hline Valparaíso & Limache & Sweet orange & $305-6 \mathrm{~B}$ & 10 & 2 & Neg & T30K17 \\
\hline Valparaíso & Limache & Sweet orange & $305-4$ & 13 & 2 & Neg & T30K17 \\
\hline Metropolitana & Buin & Lemon & 366 & 13 & 2 & Neg & T30K17 \\
\hline Metropolitana & Melipilla & Sweet orange & 351 & 13 & 2 & $\mathrm{Neg}$ & T30K17 \\
\hline Metropolitana & Melipilla & Sweet orange & 349 & 7 & 2 & Neg & T30K17 \\
\hline Metropolitana & Paine & Sweet orange & 368 & 13 & 2 & Neg & T30K17 \\
\hline Valparaíso & Limache & Sweet orange & $305-2$ & 13 & 8 & $\mathrm{Neg}$ & T30K17 \\
\hline Tarapacá & Pica & Grapefruit & 509 & 5 & 1 & Pos & Only T36CP ${ }^{2}$ \\
\hline Tarapacá & Pica & Grapefruit & 507 & 5 & 1 & Pos & Only T36CP \\
\hline Tarapacá & Pica & Grapefruit & 512 & 10 & 1 & Pos & Only T36CP \\
\hline Tarapacá & Pica & Grapefruit & 516 & 10 & 1 & Pos & Only T36CP \\
\hline Tarapacá & Pica & Grapefruit & 517 & 10 & 1 & Pos & Only T36CP \\
\hline Tarapacá & Ovalle & Lemon & 495 & $\mathrm{ND}_{3}$ & 1 & Pos & Only T36CP \\
\hline Tarapacá & Pica & Grapefruit & 525 & 7 & 1 & Pos & Only T36CP \\
\hline Atacama & Vallenar & Sweet orange & 502 & 13 & 2 & $\mathrm{Neg}$ & Only T36CP \\
\hline Valparaíso & Limache & Sweet orange & $305-11$ & 13 & 2 & $\mathrm{Neg}$ & Only T36CP \\
\hline Valparaíso & Limache & Sweet orange & $305-12$ & $\mathrm{ND}_{1}$ & 2 & Neg & Only T36CP \\
\hline Valparaíso & Limache & Sweet orange & $305-18$ & 7 & 2 & $\mathrm{Neg}$ & Only T36CP \\
\hline Valparaíso & Limache & Sweet orange & $305-19$ & $\mathrm{ND}_{4}$ & 2 & Neg & Only T36CP \\
\hline Valparaíso & Limache & Sweet orange & $305-19 B$ & 7 & 2 & Neg & Only T36CP \\
\hline Metropolitana & Paine & Sweet orange & 369 & 13 & 2 & Neg & Only T36CP \\
\hline O’Higgins & Doñihue & Sweet orange & 492 & 7 & 2 & Neg & Only T36CP \\
\hline O'Higgins & Las Cabras & Sweet orange & 467 & 7 & 2 & $\mathrm{Neg}$ & Only T36CP \\
\hline O'Higgins & Nancagua & Sweet orange & 461 & 7 & 2 & Neg & Only T36CP \\
\hline O'Higgins & Nancagua & Sweet orange & 463 & 7 & 2 & $\mathrm{Neg}$ & Only T36CP \\
\hline O'Higgins & Peumo & Sweet orange & 389 & 7 & 2 & Neg & Only T36CP \\
\hline O'Higgins & Peumo & Sweet orange & 503 & $\mathrm{ND}_{4}$ & 2 & $\mathrm{Neg}$ & Only T36CP \\
\hline O'Higgins & Peumo & Sweet orange & 504 & $\mathrm{ND}_{1}$ & 2 & $\mathrm{Neg}$ & Only T36CP \\
\hline O’Higgins & Sta. Cruz & Sweet orange & 460 & 13 & 2 & $\mathrm{Neg}$ & Only T36CP \\
\hline Coquimbo & Ovalle & Lemon & 494 & 5 & 3 & Pos & Only T36CP \\
\hline Coquimbo & Ovalle & Lemon & 497 & 9 & 3 & Pos & Only T36CP \\
\hline Coquimbo & Ovalle & Lemon & 496 & 13 & 6 & $\mathrm{Neg}$ & Only T36CP \\
\hline
\end{tabular}

${ }^{1}$ The abbreviations express the amplified markers VT (complete), VT5' (only VT5'), T30POL (only T30 Pol marker), T30K17 (only marker K17 of T30 isolate), (-) absence of a band for the corresponding marker, (+) presence of a band for the corresponding marker.

${ }^{2}$ Only one band obtained corresponds to the universal T36 CP marker.

Pos, MCA13-positive reaction (Permar et al., 1990).

Neg, MCA13-negative reaction.

Table serological group check Besoain (2008).

ND, Not determined. 
group 1. The second largest group (serogroup 2) was composed of the CTV isolates (34\%) that reacted to all of the MAbs with the exception of MCA13.

Sixty percent of the CTV isolates in this study were MCA13-positive (serogroups 1, 3 and 4), almost all of which came from the Tarapacá Region, with the exception of three isolates from Ovalle (Coquimbo Region) and one from Limache (Valparaíso Region). Alternatively, almost all of the isolates from the central zone were MCA13-negative (serogroups 2, 5, 6, 7 and 8) (Table 2). However, 10 of the 11 isolates that caused the SP reaction in Duncan grapefruits were MCA13-positive, and all 6 isolates that caused SP in sweet oranges were MCA13-positive (Tables 1 and 2).

\section{Molecular characterization}

Based on the analysis of the RT-PCR amplification with the 11 different combinations of primer pairs (Table 2), it was possible to infer that the Chilean CTV isolates tended to be grouped as follows: VT type, total and partial (47\%); T30 type, total or partial (21\%); those that showed zones of the genome of T30 plus the VT (7\%); and finally a group of isolates that were only recognized by the pair of universal primers T36CP (25\%). There was a correlation between the type of isolate and geographic location. For example, the VT type was located primarily in the Tarapacá area, which was the zone where the greatest losses and deterioration associated with severe stem pitting of trees occurred (Figure 1 A and B). Only one isolate of the VT type was found in the Atacama Region; this isolate was specifically located in an old-fashioned variety garden, which agreed with the information gathered in the field that grapefruit cuttings had been taken for new plantings in the oases of Pica and Matilla in the Tarapacá Region (unpublished data).

\section{Global analysis}

Table 2 shows the description of the 100 Chilean CTV isolates selected for this study based on their biological, serological and molecular characteristics. Of the $58 \mathrm{CTV}$ isolates from the Tarapacá Region, 56 reacted with MCA13 and were catalogued as the VT genotype and 52 provoked noticeable symptoms on the indicator plants (DI on sour/ sweet oranges and SY or SP) (Table 1 and 2). This clear correlation indicates that an integral approach (biological, serological, and molecular) should be used to classify CTV isolates. Nevertheless, isolates were also found in the oases of Pica and Matilla in the Tarapacá Region that were considered to be aggressive in the biological indexing but caused no apparent symptoms in the infected orchard-grown trees after a repeat visit four years later in 2006 despite the fact that some of them demonstrated an MCA13-positive reaction (isolates 301-34, 30134B and 301-44B).

The Chilean CTV isolates that produced amplicons whose sequences were associated with the T30 genotype were mainly from the central zone. These isolates were observed to be less aggressive in the biological characterization and were MCA13-negative, although some were capable of causing SY in sour oranges (isolates 305-3, 305-8, 305-5B and 305-6B) (Table 2).

Finally, there were a total of $25 \mathrm{CTV}$ isolates that were recognized only by T36CP. Many of these isolates were from the Tarapacá Region and central Chile, but could not be grouped with any known type of isolate (Table 2). Additionally, the Spanish isolates considered to be mild that were used in this study (T-300 and T302) also amplified only the T36CP region. However, some of these isolates $(509,512,516,517$ and 495) were capable of producing symptoms associated with aggressive isolates in indicator plants under greenhouse conditions (profiles 2, 3, 5, 5, 8, 9, 10 and 12) (Table 1 and 2, Figure 1C and D). 


\section{Discussion}

\section{Biological characterization}

Based on the results obtained from the biological characterization, the aggressive isolates detected in Chile corresponded to isolates primarily from the Tarapacá Region. These isolates exhibited a positive reaction to the MCA13 monoclonal antibody (Permar et al., 1991) and a positive amplification of some of the markers of the VT genotype (Hilf et al., 2005). All of the CTV isolates from this region had positive results for at least one of these two reactions.

Ninety percent of the CTV isolates from the central zone were found to be not very aggressive biologically, were MCA13-negative, and had no amplification of the bands associated with the VT isolates. However, $50 \%$ of these isolates caused a DI reaction according to the test proposed by Pina et al. (2004). Nevertheless no DI symptoms were observed in the previous survey associated with sweet orange trees grafted on sour orange (Besoain, 2008).

The absence or decline of orchards with sweet orange trees grafted onto sour oranges under field conditions could be attributed to a lack of transmission of these isolates by aphids. These orchards were located in similar conditions to orchards in California or the Mediterranean area where severe DI-epidemics have occurred (Moreno et al., 2008).

\section{Serological characterization}

One hundred percent of the isolates were recognized by the mix of the MAbs 3DF1 + 3CA5 that were described as universal (Cambra et al., 1991). The MCAs that could detect all of the Chilean isolates were 3DF1 and 3BH6 from Spain (Vela et al., 1986) and $\alpha \mathrm{CTV} 4 \mathrm{E} 5-\mathrm{a} 1$ and $\alpha \mathrm{CTV} 4 \mathrm{~B} 1-3$ from Morocco (Besoain, 2008). Nevertheless, two isolates (496 from a lemon tree in Ovalle
(Coquimbo Region) and 281-1 from a sweet orange from Vallenar (Atacama Region)) did not react to the MAb 3CA5, which is considered to be a wide spectrum MAb. Very few CTV isolates that are defective in the 3CA5 epitope have been described (Cambra et al., 1993).

The isolates belonging to groups 3 to 8 possibly contain more simple populations than those in groups 1 and 2. For the characterization of the reference isolates, strain T-300 exhibited the behavior described by Cambra et al. (1993) and was classified among group 2. In contrast, strains T-388 and T-397 reacted positively to all of the antibodies and were serologically classified as group 1, while isolate T-397-P with the defective 3DF1 epitope reacted with neither 3DF1 nor 3BH6. Finally, MCA 3E10 was not capable of discriminating between the aggressive and mild isolates (Table 1). This finding did not agree with the observations of Tsai et al. (1993), who found it to have a behavior similar to MCA13.

\section{Molecular characterization}

The universal primers Pin 1 and Pin 2 (Bertolini et al., 2008), the T36CP primers (Hilf and Garnsey, 2000) and those designed by Bertolini et al. (2008) for real-time PCR were capable of recognizing $100 \%$ of the Chilean CTV isolates used in this study.

The majority of the Chilean isolates (33\%) (Table 2) were included in biological group 7 (capable of causing DI in sweet orange/sour orange) but were grouped into different serogroups (up to 5), suggesting serological diversity. Moreover, these isolates were genotyped by RT-PCR as belonging to four groups (although they were primarily VT), indicating variability. The second relatively frequent group of CTV isolates in Chile was cataloged biologically as typical of group 13 , which was only capable of inducing symptoms in Mexican limes. Nevertheless, some of these isolates reacted to MCA13 and their molecular 
profile was grouped with VT, T30 + VT, or only CPT36, all of which denoted variability. None of these isolates caused important symptoms in their original hosts in the field. This reaffirms the importance of isolate characterizations that are not based only on biological characteristics (as suggested by Garnsey et al. (1987)) but also include serological and molecular characteristics (Wang et al., 2013).

The third most frequent group in Chile (18\% of the CTV isolates studied) also showed variability; these isolates belonged to serogroups 1 or 2 and were grouped by RT-PCR as T30, VT and VT + T30. These isolates were grouped biologically in group 4 (capable of inducing DI in sour/sweet and SY in sour oranges). Nevertheless, none of these isolates caused significant symptoms in their original hosts in the field.

In this study, there was agreement between the geographical location of the CTV isolates, their serological reaction to MCA13, and the molecular isolate-type to which they belonged. For example, the isolates originating in the Tarapacá Region were classified as MCA13-positive and VT. These isolates caused symptoms of extreme stem pitting in the wood to similar extents in the field and in the biological tests. In contrast, a low incidence of isolates with aggressive characteristics was detected in central Chile where the principal commercial orchards are located. However, this situation could change in the future, thereby demonstrating the importance of producing propagation material free of CTV and introducing new improvements in the detection of viruses and viroids.

\section{Acknowledgements}

Thanks to Teresa Álvarez, Gladys Andrade, Iván Cortes (PUCV-Pontificia Universidad Católica de Valparaíso, Chile) and Consuelo Collado (IVIA- Instituto Valenciano de Investigaciones Agrarias, Spain) for technical assistance, to Mauricio Cisternas and Ramiro Vera (PUCV) for field sampling and to the Micropropagation Laboratory (PUCV) for citrus materials for the biological indexing. Funded by: FONDO-SAG, V1-15-0199; DGI-PUCV242.706/03; and MECESUP UCV002.

\section{Resumen}

X. Besoain, E. Bertolini, R. Camps, F. Ramella, , M.T. Gorris, M. Torres y M. Cambra. 2015. Aislados agresivos de Citrus tristeza virus en Chile son MCA13 positivo y tipo VT mientras que los aislados leves son MCA13 negativo y tipo T30. Cien. Inv. Agr. 42(2):251262. El virus de la tristeza de los cítricos fue reportado el año 1960 afectando a árboles de limonero Meyer pero no se observaron síntomas a nivel de campo. Esta investigación tuvo como objetivo realizar una completa caracterización biológica, serológica y molecular de 100 aislados Chilenos de Citrus tristeza virus (CTV), previamente obtenidos desde diferentes hospederos y regiones geográficas. No se encontró síntomas de decaimiento (DI) en arboles injertados sobre naranjo amargo. En el Oasis de Pica, localidad de la zona norte de Chile, fue encontrada tristeza causando Stem pitting (SP) en árboles de pomelo y lima Mexicana. La mayoría de los aislados presentes en la zona central se consideraron leves (MCA-13 negativos), mientras que en la zona norte se observaron y se detectaron aislados agresivos, algunos capaces de causar SP en pomelo en condiciones campo e invernadero, y algunos capaces de causar SP en naranjo dulce bajo condiciones de invernadero, de los cuales casi todos fueron MCA-13 positivos y la secuencia de nucleótidos asociada al genotipo VT.

Palabras clave: Acanaladura de la madera, amarillez de plantas, caracterización molecular, CTV, Prueba biológica. 


\section{References}

Ballester-Olmos, J.F., E.A. Carbonell, P. Moreno, A. Hermoso De Mendoza, M. Cambra, and L. Navarro. 1993. Biological diversity spread of citrus tristeza virus (CTV) in Spain. Plant Pathology 42:219-229.

Brlansky, R., A. Roy, and V. Dansteegt. 2011. Stempitting Citrus tristeza virus predominantly transmitted by the brown citrus aphid from mixed infections containing non-stem-pitting and stempitting isolates. Plant Disease 95:913-920.

Bertolini, E., A. Moreno, N. Capote, O. Olmos, A. De Luis, E. Vidal, J. Pérez-Panadés, and M. Cambra. 2008. Quantitative detection of Citrus tristeza virus in plant tissues and single aphids by Real-time RT-PCR. European Journal of Plant Pathology 120:177-188.

Besoain, X. 2008. Incidencia, caracterización y epidemiologia del virus de la tristeza de los cítricos en Chile. Tesis Doctoral. Universidad Politécnica de Valencia. Escuela Técnica Superior de Ingenieros Agrónomos. Valencia, España. 129 pp.

Biswas, K.K. 2010. Molecular characterization of Citrus tristeza virus isolates from the Northeastern Himalayan region of India. Archives of Virolology 155:959-963.

Broadbent P., R.H. Brlansky, and J. Indsto. 1996. Biological characterization of Australian isolates of citrus tristeza virus and separation of subisolates by single aphid transmissions. Plant Disease 80:329-333.

CABI, 2010. Citrus tristeza virus (Distribution map). 2010. Distribution Maps of Plant Diseases, April, Map 289 (Edition 7).

Cambra, M., S.M. Garnsey, T.A. Permar, C.T. Henderson, D. Gumpf, and C. Vela. 1990. Detection of citrus tristeza virus (CTV) with a mixture of monoclonal antibodies. Phytopathology 80:1034.

Cambra, M., E. Camarasa, M.T. Gorris, S.M. Garnsey, and E. Carbonell. 1991. Comparison of different inmunosorbent assays for Citrus tristeza virus (CTV) using CTV-specific monoclonal and polyclonal antibodies. p. 38-45. In: Proc 11th conf. International Organization of Citrus Virologists (IOCV): IOCV Riverside, California.
Cambra, M., E. Camarasa, M.T. Gorris, S.M. Garnsey, D.J. Gumpf, and M.C. Tsai. 1993. Epitope diversity of isolates of citrus tristeza virus (CTV) in Spain. p. 33-38. In: Proc 12th conf. International Organization of Citrus Virologists (IOCV): IOCV Riverside, California.

Cambra, M., and P. Moreno. 2000. Tristeza. In: P. Moreno, N. Durán-Vila (eds.). Enfermedades de los cítricos. Monografía de la Sociedad Española de Fitopatología. №2. Madrid. Ediciones Mundi-Prensa. $213 \mathrm{pp}$.

Garnsey, S.M., D.J. Gumpf, C. Roistacher, E. Civerolo, R. Lee, R. Yokomi, and M. Bar-Joseph. 1987. Toward standardized evaluation of the biological properties of citrus tristeza virus. Phytophylactica 19:151-157.

Harper, S.J. 2013. Citrus tristeza virus: evolution of complex and varied genotypic groups. Frontiers in Microbiology 93:1-18.

Hilf, M.E., and S.M. Garnsey. 2000. Characterization and classification of Citrus tristeza virus isolates by amplification of multiple molecular markers. p. 18-27. In: Proc 14th conf. International Organization of Citrus Virologists (IOCV): IOCV Riverside, California.

Hilf, M.E., V.A. Mavrodieva, and S.M. Garnsey. 2005. Genetic marker analysis of a global collection of a Citrus tristeza virus: Characterization and distribution of CTV genotypes and association with symptoms. Phytopathology 95:909-917.

Moreno, P., S. Ambrós, M. Albiach-Martí, J. Guerri, and L. Peña. 2008. Plant diseases that changed the world Citrus tristeza virus: a pathogen that changed the course of the citrus industry. Molecular Plant Pathology 9:251-268.

ODEPA, 2013. Portal de información de la agricultura chilena. Available online at: http://www.odepa. cl/wp-content/files_mf/1388424450Mandarinas. pdf (Website accessed: June 25, 2015).

Olmos, A., M. Cambra, O. Esteban, M.T. Gorris, and E. Terrada. 1999. New device and method for capture, reverse transcription and nested PCR in a single closed-tube. Nucleic Acids Research 27:1564-1565.

Permar, T., S. Garnsey, D. Gumpf, and R. Lee. 1990. A monoclonal antibody that discriminates strains 
of citrus tristeza virus. Phytopathology 80:224228.

Permar, T., and S. Garnsey. 1991. Comparison of biological indexing and immunological assays for identifying severe Florida isolates of Citrus tristeza virus. p. 56-59. In: Proc 11th conf. International Organization of Citrus Virologists (IOCV): IOCV Riverside, California.

Pina, J., P. Moreno, J. Juárez, J. Guerri, M. Cambra, M. Gorris, and L. Navarro. 2004. A new procedure to index for Citrus tristeza virus induced decline on sour orange rootstock. p. 47. In: Proc 16th conf. International Organization of Citrus Virologists (IOCV): IOCV Riverside, California. Roistacher, C.N. 1991. Graft-transmissible diseases of citrus, handbook for detection and diagnosis. International Organization of Citrus Virologists, Riverside, CA (USA); FAO, Rome (Italy). Plant Production and Protection Div. FAO. Rome, Italy. 286 pp.
Tsai, M.C., H.J. Su, S. Garnsey. 1993. Comparative studies on stem-pitting strains of CTV in the Asian countries. p. 16-19. In: P. Moreno, J.V. da Graça, L.W. Timmer (eds.). Proceedings of the 12th Conference of International Organization of Citrus Virologists, IOCV, Riverside.

Vela, C., M. Cambra, E. Cortés, P. Moreno, J. Miguet, C. Pérez De Román, and A. Sanz. 1986. Production and characterization of monoclonal antibodies specific for the tristeza virus and their use for diagnosis. Journal of General Virology 67:91-96.

Wang, J., O. Bozan, S. Kwon, T. Dang, T. Rucker, R. Yokomi, R. Lee, S. Folimonova, R. Kruger, J. Bash, G. Greer, J. Diaz, R. Serna, and G. Vidalakis. 2013. Past and future of a century old Citrus tristeza virus collection: a California citrus germplasm tale. Frontiers in Microbiology 4:1-13.

Weathers, L., and L. Sánchez. 1970. Tristeza disease of citrus in Chile. Plant Disease Reporter 54:54244. 